\title{
Reproductive biology of Echinodorus grandiflorus (Alismataceae): evidence of self-sterility in populations of the state of São Paulo
}

Biologia reprodutiva de Echinodorus grandiflorus (Alismataceae): evidência de auto-esterilidade em populações do estado de São Paulo

\author{
Emerson R. Pansarin ${ }^{1}$ \& Ludmila M. Pansarin ${ }^{2}$
}

\begin{abstract}
Resumo
A biologia floral e reprodutiva de Echinodorus grandiflorus (Cham. \& Schltdl.) Micheli foram estudadas em populações nativas do interior do estado de São Paulo. A espécie floresce no verão e suas flores oferecem tanto néctar quanto pólen como recurso. O néctar é secretado por nectários localizados na base dos carpelos marginais, opostos às pétalas. Os polinizadores (abelhas sociais e solitárias), no entanto, foram observados coletando apenas pólen. As visitas, que podem durar de um a poucos segundos até mais de um minuto, acontecem desde o momento da abertura das flores (ca. 5:30 h) até o fenecimento. Cada flor dura cerca de oito horas. Todos os indivíduos das populações produzem apenas flores hermafroditas. A porcentagem de grãos de pólen viáveis é de 75\%. As populações estudadas são autoincompatíveis e, como conseqüência, polinizadores são necessários para transferência de pólen. Em condições naturais e a partir das polinizações cruzadas realizadas manualmente, todos os receptáculos apresentaram aquênios maduros. Através das análises dos tubos polínicos das flores autopolinizadas manualmente, e devido ao fato dos aquênios derivados desse tratamento abortarem cerca de 30 dias a partir das autopolinizações, aparentemente, as populações de E. grandiflorus estudadas apresentam um mecanismo de auto-esterilidade de ação tardia.
\end{abstract}

Palavras-chave: Alismataceae, auto-compatibilidade, biologia da polinização.

\begin{abstract}
The reproductive biology and the pollination of Echinodorus grandiflorus (Cham. \& Schltdl.) Micheli were studied in populations native to interior of the State of São Paulo, Brazil. This species blossoms in summer and its flowers offer both nectar and pollen as rewards to pollinators. Nectar is produced in nectaries located at the base of the marginal carpels, opposite the petals. However, the effective pollinators (social and solitary bees), were recorded collecting pollen only. Visits, which can last from one or a few seconds to more than one minute, occur during the whole flower lifespan. Each flower opens at about 5:30 a.m. and lasts circa eight hours. All plants in the studied populations produce only hermaphrodite flowers. Percentage of pollen viability is $75 \%$. The studied populations are self-incompatible and, as a consequence, pollinators are needed to transfer pollen among individuals. In natural conditions and after hand cross-pollinations, all receptacles presented mature achenes. Based on the analyses of pollen tube growth from hand self-pollinated flowers, and as a consequence of achenes abortion circa 30 days after self-pollinations, the populations of $E$. grandiflorus studied apparently presents a mechanism of late-acting self-sterility.
\end{abstract}

Key words: Alismataceae, pollination biology, self-compatibility.

\section{Introduction}

Alismataceae is subcosmopolitan and it is represented in the temperate, subtropical and tropical regions of both hemispheres (Haynes \& Holm-Nielsen 1994). This family includes circa 80 species distributed in approximately 11 genera, three of which occur in Brazil: Echinodorus Rich., Sagittaria L. and Helanthium (Benth. \& Hook.f.)
Engelm. ex J.G. Sm. Echinodorus is one of its largest genera, with 26 species distributed exclusively on the American Continent, from Northern United States to Argentina (Rataj 1978). In the State of São Paulo, Echinodorus is represented by seven species that grow in aquatic habitats, since they are found in fresh or briny water or on marshy soils (Pansarin \& Amaral 2005).

\footnotetext{
${ }^{1}$ University of São Paulo, FFCLRP, Dept. Biology, Av. Bandeirantes 3900, 14040-901, Ribeirão Preto, SP, Brazil. Corresponding author: epansarin@ffflrp.usp.br ${ }^{2}$ State University of Campinas, Post-Graduation Program in Plant Biology, Institute of Biology, Dept. Plant Biology, C.P. 6109, 13083-970, Campinas, SP, Brazil.
} 
Data on the floral and reproductive biology involving neotropical species of Echinodorus are scarce in the literature and only concern two species: E. longipetalus Micheli (Pansarin 2008) and E. grandiflorus (Cham. \& Schltdl.) Micheli (Vieira \& Lima 1997), which are pollinated by native bees (Vieira \& Lima 1997; Pansarin 2008).

The main characteristic used to differentiate Echinodorus and Sagittaria, two genera occurring in Brazil, is the production of hermaphrodite and unisexual flowers, respectively (Haynes \& HolmNielsen 1994; Pansarin \& Amaral 2005). Yet, Pansarin (2008) reported the occurrence of gynodioecy for E. longipetalus, in populations of rural areas of the State of São Paulo. According to the classification by Haynes \& Holm-Nielsen (1994), E. grandiflorus present two subspecies. Both occur in the State of Minas Gerais and present different reproductive systems: E. grandiflorus (Cham. \& Schltdl.) Micheli ssp. aureus (Fasset) Haynes \& Holm-Nielsen is self-compatible, while $E$. grandiflorus (Cham. \& Schltdl.) Micheli ssp. grandiflorus Haynes \& Holm-Nielsen is selfincompatible (Vieira \& Lima 1997). Nevertheless, phylogenetic analyses based on morphological (Lehtonen 2008) and molecular (Lehtonen \& Myllys 2008 ) data show that E. grandiflorus is part of a paraphyletic group. Based on such data, Lehtonen (2008) currently considers E. grandiflorus ssp. aureus as a synonym for E. floribundus (Seub.) Seub. and E. grandiflorus ssp. grandiflorus as a synonym for $E$. grandiflorus.

Echinodorus grandiflorus (sensu Lethonen 2008) occurs in South America and in Florida (U.S.A.). In the state of São Paulo, it is a widespread species, found throughout the state (Pansarin \& Amaral 2005). Its flowers are hermaphrodite (Vieira \& Lima 1997; Pansarin \& Amaral 2005; Pansarin 2009), and offer both pollen and nectar to their visitors (Vieira \& Lima 1997).

Campbell (1987) discussed the problems brought on by generalizations made in studies on floral biology carried out in a single study region. When studies involving widely distributed species are carried out in more than one area, differences are observed with regard to their pollination systems (Smith \& Snow 1976; Cole \& Firmage 1984). Based on these assertions, the present work investigated the reproductive system of E. grandiflorus in populations native to the rural area of Ribeirão Preto, State of São Paulo, through studies on floral morphology, pollinators and pollination mechanisms, reproductive systems and fruiting rates in natural environments.

\section{Material and methods \\ Place of study}

This study was carried out in marshy areas of rural areas around Ribeirão Preto, State of São Paulo, namely in the townships of Jaboticabal (circa $21^{\circ} 15^{\prime} \mathrm{S}$ and $48^{\circ} 19^{\prime} \mathrm{W}$ ), Luiz Antônio (circa $21^{\circ} 33^{\prime} \mathrm{S}$ and $47^{\circ} 42^{\prime} \mathrm{W}$ ), Matão (circa $21^{\circ} 16^{\prime} \mathrm{S}$ and $48^{\circ} 22^{\prime} \mathrm{W}$ ) and Sertãozinho (circa $21^{\circ} 08^{\prime} \mathrm{S}$ and $47^{\circ} 59^{\prime} \mathrm{W}$ ). The region of Ribeirão Preto is located in the northwestern part of the State of São Paulo and has a mean altitude of $555 \mathrm{~m}$, with regular reliefs and some plateau areas. Mean annual temperature varies between $17^{\circ} \mathrm{C}$ and $28^{\circ} \mathrm{C}$. Climate is mesothermic, with humid summers and dry winters, considered as "Cwa" in Köppen's classification (1948). The rainy season and high temperatures occur from October to March, and the dry season from May to August. Dark red latosol, sandy phase, originating from sandstones, covers almost half of the territory of the region. Purple latosol is found in the lower parts of the territory and it originates from the decomposition of basalt rocks (e.g., Centurion $e t$ al. 1995; Pissarra et al. 2004). The native flora is predominantly composed by mesophytic, seasonal semi-deciduous forests. Yet, the advance of monocultures, initially coffee and, more recently, sugar cane, has significantly reduced native wood areas in that region. Nowadays only forest fragments remain, essentially on river and creek banks (Pinto 1989).

\section{Studied species}

Echinodorus grandiflorus is found in aquatic habitats and on marshy soils (Pansarin \& Amaral 2005). It is easily recognized by it large leaf blades usually oval, with cordate base and translucent marks forming points or points and lines. Echinodorus grandiflorus also has very characteristic paniculiform cymose inflorescences that produce many white flowers. Gynoecium is apocarpic and androecium presents many stamens free from each other. Fruits are achenes (Haynes \& Holm-Nielsen 1994; Pansarin \& Amaral 2005).

\section{Floral phenology and morphology}

Visits to field were conducted monthly, from November 2007 to March 2008, in order to determine 
the phenological patterns of Echinodorus grandiflorus in the studied populations. To do so, we surveyed leaf, inflorescence, flower, and fruit production periods. We also controlled the time and sequence of anthesis, the duration of each flower, in addition to the reward availability and production period checked while observing pollinators and pollination mechanisms. During flowering period, between October and March, field visits were intensified to obtain more data on the floral and reproductive biology of this species.

The fresh material of flowers of Echinodorus grandiflorus collected in the townships of Matão $(\mathrm{n}=98 ; 49$ plants; 49 inflorescences), Jaboticabal ( $\mathrm{n}=60 ; 3$ plants; 3 inflorescences), Sertãozinho ( $\mathrm{n}=60 ; 4$ plants; 4 inflorescences) and Luiz Antonio ( $\mathrm{n}=30$; 1 plant; 1 inflorescence) was analyzed with the help of magnifying glass binoculars. We observed the form, symmetry, disposition and size of floral structures such as sepals, petals, anthers, and related them to both the morphological features of the pollinators and the pollination mechanism (Faegri \& van der Pijl 1980).

To investigate the occurrence of gynodioecy, the production of pollen grains by the anthers of fresh flowers collected in the field $(\mathrm{n}=98)$ was verified according to Pansarin (2008). Furthermore, to ascertain pollen grain viability, anthers were macerated in a solution of acetic carmine and observed under an optical microscope (Radford et al. 1974). For each flower 200 pollen grains were sampled.

The anatomical analyses of the nectar secreting structures were carried out on newly opened flowers $(n=6)$ collected in the field. Flowers were previously fixed in FAA 50\% (Johansen 1940) and dehydrated in butyl series (tertiary butyl alcohol), embedded in paraffin according to the method described in Sass (1951) and cut with a rotative microtome. The cuts $(4 \mu \mathrm{m})$ were then stained with safranin and Astra blue 1\%, and the slides were mounted in synthetic resin.

Plant material was deposited at the herbarium of the University of São Paulo (SPFR): E.R. Pansarin \& J.F. Sicchieri 1275, 1288, 1289 and 1290.

\section{Reproductive system}

Between November 2008 and February 2009, treatments were carried out to verify the reproductive system of Echinodorus grandiflorus in the populations of the township of Sertãozinho
(4 plants; 5 inflorescences), Matão (3 plants; 4 inflorescences), Jaboticabal (3 plants; 3 inflorescences) and Luiz Antonio (2 plants; 2 inflorescences). Four types of treatments were performed on inflorescences previously enclosed in tulle bags (Kearns \& Inoye 1993): hand selfpollination $(\mathrm{n}=240)$, spontaneous self-pollination $(\mathrm{n}=189)$, cross-pollination $(\mathrm{n}=129)$ and emasculation $(n=60)$. Treatments were randomly applied to each inflorescence. Floral buds were emasculated before the occurrence of anthesis (circa 5:00 a.m.) and cross- and self-pollinations were performed between 8:30 a.m. and 10:30 a.m.

In addition, both hand self-pollinations $(\mathrm{n}=$ 30) and cross-pollinations $(n=30)$ were carried out on individuals that had been collected in the field (population of Matão) and were cultivated for over a year in the aquatic plant tanks of the Sector of Botany (Department of Biology, FFCLRP, USP), municipality of Ribeirão Preto (circa $21^{\circ} 09^{\prime} S$ and $\left.47^{\circ} 51^{\prime} \mathrm{W}\right)$. Pollen tube growth of the aborted flowers produced through self-pollinations was analyzed. Flowers were fixed in Carnoy's solution for $24 \mathrm{~h}$, and then transferred to $70 \%$ alcohol. To mount the slides, the material was then immersed in $\mathrm{NaOH}$ for a mean time of 30 minutes, washed in distilled water, stained with aniline blue, compressed under a coverslip and observed under a fluorescence microscope (Martin 1959).

Fruiting rates in natural environment (open pollination) were verified on 5,965 receptacles (30 infrutescences; 30 plants) collected in the population of the township of Sertãozinho.

The number of flowers producing fruits, as well as the total number of achenes yielded after our treatments and on the infrutescences collected in the field were also assessed. Fruiting rates (in the field and after treatments) were quantified when achenes were mature. The number of fruits was estimated by weighing 200 achenes on a precision analytical balance $(0.0001 \mathrm{~g})$.

\section{Flower visitors}

Field visits to observe flower visitors and the pollination process of the species were conducted in two of the studied populations, in the townships of Sertãozinho and Matão. The observations of the Sertãozinho population were performed from November 24th to December 03rd, 2008. In the township of Matão, they took place between December 05th and 07th, 2007 and between December 21st and 24th, 2008. In both 
places, they occurred between 5:30 a.m. and 1:30 p.m. (between flower opening and withering), totaling 136 hours.

Flower visitors were collected, identified and deposited in the collection of the Zoology Museum of the University of São Paulo (MZUSP).

\section{Results}

Floral phenology and morphology - In all the studied regions, Echinodorus grandiflorus grows in marshy habitats, on river and creek banks, in waterlogged places or on marshy soil. During the drier periods of the year, in autumn and winter, plants do not have leaves and only present roots, stems and subterranean rhizomes. In spring, with the first rains (October), rhizomes resprout and each plant produces various petioled, rosulate leaves with very evident cordate blades. Each individual then develops one or more, albeit rarely two, lateral inflorescences that produce up to 250 flowers. Flowering period is from November to February (spring to summer), with a peak in December and January. During flowering, each plant may present up to 15-20 open flowers per day, which open at sunrise (approximately 5:30 a.m.) and last circa 8 hours. No morphological differences were registered among the flowers of the different studied populations.
Flowers are trimerous, pedicelled and hermaphrodite (Fig. 1a). Sepals (5.6-7.3 $\times 4.5-7.3 \mathrm{~mm}$ ) are green, coriaceous, and persistent, and protect the achenes while they ripen. Petals $(2-2.5 \times 2.3-2.5 \mathrm{~cm})$ are white, frail andephemeral. Stamens (ca. 25-30) are arranged in various whorls around the gynoecium (Fig. 1a-b). Anthers measure $1.6 \mathrm{~mm}$, are versatile and all present viable pollen grains. Anther opening coincides with flower anthesis. Pollen grain viability is $75 \%(\mathrm{n}=19,600)$. The apocarpic gynoecium presents numerous pistils, each bearing a single ovule and a rudimentary stigma at apex. Mature achenes are scattered between February and March.

The flowers of Echinodorus grandiflorus offer both nectar and pollen to their visitors. Nectar is secreted at the base of the peripheral carpels, opposite the petals (Fig. 2a). The secretory tissue is composed of a single layer of oval, juxtaposed epidermal cells (Fig. 2b) that have a strongly stained, dense cytoplasm, and a welldeveloped nucleus (Fig. 2b), characteristic of metabolically active cells. The subjacent tissue comprises parenchymatous cells that are apparently not involved in the process of nectar secretion.

\section{Reproductive system}

The populations of Echinodorus grandiflorus here studied are self-sterile and only produce fruits through cross-pollinations
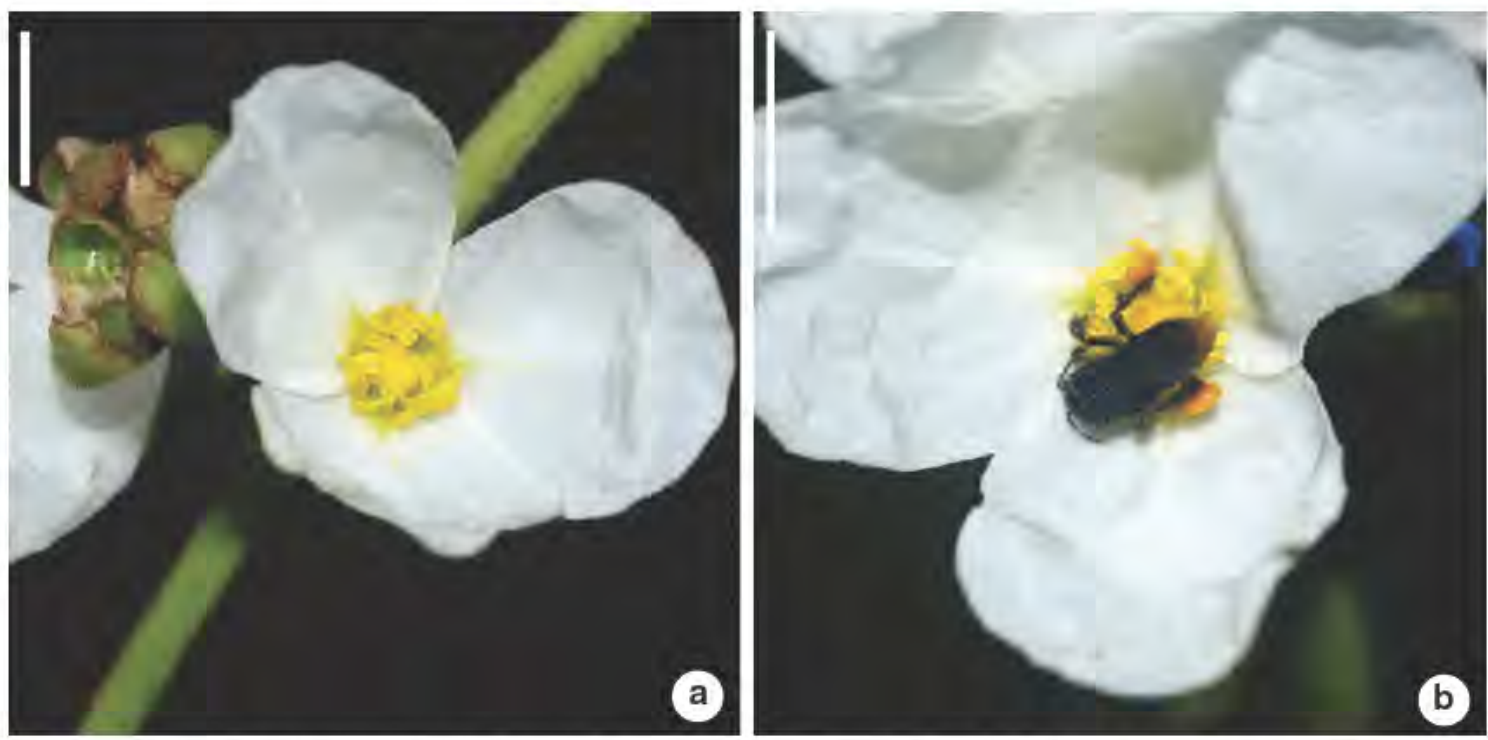

Figure 1 - a-b. Echinodorus grandiflorus (Cham. \& Schltdl.) Micheli - a. detail of a flower, note the numerous stamens around the apocarpic ovary and the nectar guides at petal base; b. Trigona spinipes Fabricius collecting pollen from flower anthers, note their corbiculae full of pollen grains. Scale bars $=1 \mathrm{~cm}$. 
Reproductive biology of Echinodorus grandiflorus

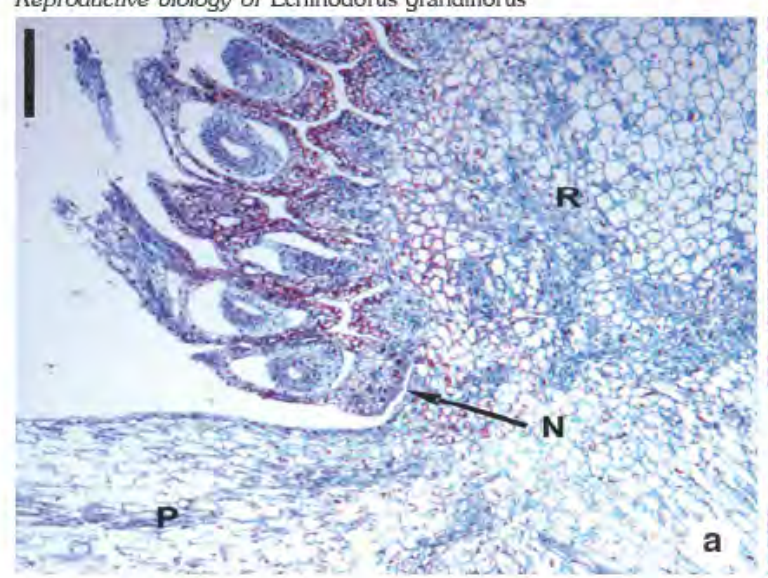

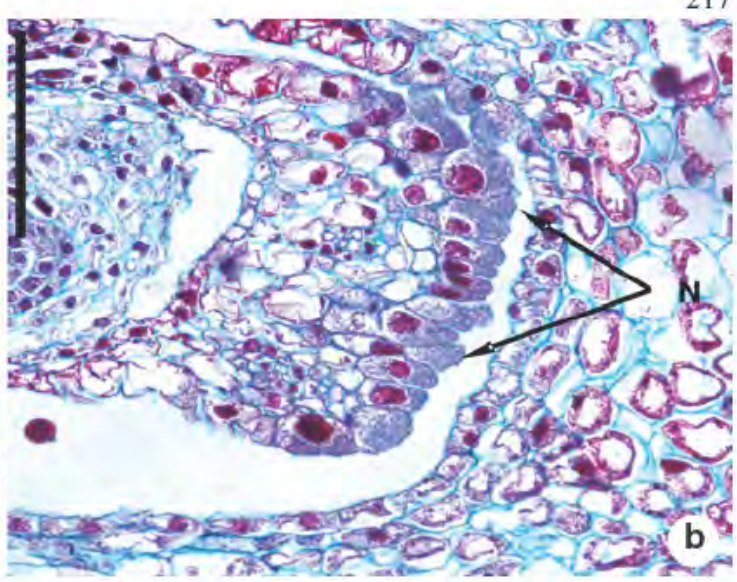

Figure 2 - a-b. Longitudinal sections of a flower of Echinodorus grandiflorus (Cham. \& Schltdl.) Micheli - a. detail of the receptacle $(\mathrm{R})$ and the nectary $(\mathrm{N})$, located on the margin of the more distal carpel (arrow), opposite the petal (P); b. detail of the nectary $(\mathrm{N})$ evidencing the nectar secretory epidermal cells (arrow). Scale bars $=100 \mu \mathrm{m}$.

(Tab. 1). No fruits were formed in flowers that were emasculated, manually self-pollinated or spontaneously self-pollinated (untouched flowers) (Tab. 1). Thus, a pollinator is necessary to transfer pollen among different individuals of the populations. Fruits are mature circa 45 days after cross-pollinations. In natural conditions, fruiting rates are high (Tab. 1). All the sampled (cross- and open-pollinated) flowers presented mature achenes (predated receptacles were excluded). Achene production in each receptacle is higher after crosspollinations (mean of 250 fruits) than in natural conditions (mean of 190 fruits). The reproductive system of $E$. grandiflorus is presented in Table 1.

Achenes yielded after hand self-pollination treatment aborted tardily, circa 30 days after manipulations. The analyses of the pollen tube growth of the manually self-pollinated flowers showed that the tubes had reached the ovules, but no evidence of fertilization was found.

\section{Flower visitors}

The flowers of Echinodorus grandiflorus are visited by various species of beetles, flies and bees. Nevertheless, only species of solitary and social bees really act as pollinators (Tab, 2). All the bee species collect pollen from the flowers. We never observed bees accessing the nectar produced in the nectaries located at the base of the marginal carpels. Beetles were seen feeding on floral pieces (petals, stamens and pistils), damaging flowers and often making them inaccessible to effective pollinators. Flies of the family Bombyllidae were the only visitors to collect nectar from the flowers.
Nevertheless, their long proboscides give them access to the reward without touching the stamens and, therefore, they were not seen acting as pollinators of E. grandiflorus.

All the bee species except Xylocopa suspecta presented similar behaviors when collecting pollen. They usually landed either on the petals before heading to the stamens or directly on the anthers and pistils. They collected pollen grains fromeach anther with their front and middle legs and then transferred it to their hind legs. When collecting pollen, bees contacted the stigmas with ventral part: legs, thorax and abdomen (Fig. 1b), where pollen grains get attached. Xylocopa suspecta landed directly on the receptacle (anthers and pistils) and collected pollen from various stamens simultaneously by buzz-pollination. During these vibratory movements, great quantities of pollen were also deposited on the stigmas. Bees of the family Halictidae sometimes performed buzz-pollination, but on one anther at a time.

Bees begin visiting flowers immediately after opening and continue as long as they were open. Each visit lasts from one or a few seconds to more than a minute. Individuals of Trigona spinipes (Fig. 1b) stayed even more than one minute on each single flower. Visits only took place on sunny and cloudy days. Since there is no flower anthesis when it rains, no visits were registered in these conditions. The number of bee visits could not be checked due to the great number of individuals exploiting rewards simultaneously on a one inflorescence. Bee dimension was not a limiting factor to pollination, since different-sized species were registered as pollinators of Echinodorus grandiflorus (Tab, 2). 
Table 1 - Reproductive system of Echinodorus grandiflorus: percentage of flowers that formed fruits and fruiting rate (quantity of achenes produced) after each treatment carried out and in natural conditions (open pollination). Between parentheses is the number of flowers that formed fruits/flowers.

\begin{tabular}{lcc}
\hline Treatment & Flowers that formed fruits (\%) & Quantity of achenes produced (n) \\
\hline Cross-pollination & $100(129 / 129)$ & 32,250 \\
Manually self-pollinated & $0(0 / 240)$ & - \\
Spontaneously self-pollinated & $0(0 / 189)$ & - \\
Open pollination & $100(5.965 / 5.965)$ & $1,133,350$ \\
Emasculation & $0(0 / 60)$ & - \\
\hline
\end{tabular}

\section{Discussion}

Among the genera of Alismataceae growing in Brazil (Echinodorus Rich., Sagittaria L. and Helanthium (Benth. \& Hook. f.) Engelm. ex J.G. Sm.), the production of hermaphrodite flowers is the main characteristic used to distinguish Echinodorus (including Helanthium - a genus segregated from two species classically recognized as Echinodorus, Lehtonen \& Myllys 2008) from Sagittaria (Haynes \& Holm-Nielsen 1986, 1994; Pansarin \& Amaral 2005). Nevertheless, gynodioecy (i.e., hermaphrodite and female flowers) was registered and documented for E. longipetalus in populations of the State of São Paulo (Pansarin 2008). The present study confirms that all the populations of $E$. grandiflorus studied comprise individuals that exclusively produce hermaphrodite flowers, corroborating previously published data (e.g., Rataj 1978; Haynes \& Holm-Nielsen 1986, 1994; Pansarin \& Amaral 2005), including those on Helanthium (Lehtonen \& Myllys 2008).

In all the studied populations, we verified that Echinodorus grandiflorus offers both nectar and pollen as a reward, which had been previously described in a study carried out in the township of Viçosa, in the State of Minas Gerais (Vieira \& Lima 1997). Although nectar is the most common reward among Alismataceae species, since it is described in Baldellia (Vuille 1988), Caldesia (Gituru et al. 2002), Damasonium (Vuille 1987) and Sagittaria (Wooten 1971, Sarkissian et al. 2001), and although bees were watched exploiting this kind of reward in flowers of E. grandiflorus, in addition to pollen grains (Vieira $\&$ Lima 1997), during our observations, hymenoptera were only seen collecting pollen from the flowers. In the studied populations, nectar was only exploited by flower visitors (Bombyllidae flies) that are not involved in the pollination process of this species. As is the case with E. grandiflorus, in the studied populations, the exclusive collection of pollen by bees was also reported for the hermaphrodite flowers of E. longipetalus (Pansarin 2008). Female flowers of $E$. longipetalus are pollinated by deceit, since their staminodes, albeit smaller, look like the stamens of hermaphrodite flowers (Pansarin 2008).

The presence of nectary at the base of the marginal carpels opposite the petals, as in the flowers of $E$. grandiflorus, is common in Alismataceae species that offer nectar as a reward. This family comprises other genera that also secret nectar at the base of the filaments and petals (Pansarin 2009).

Studies of floral biology involving species of Echinodorus (Vieira \& Lima 1997; Pansarin 2008) reveal that the flowers are exclusively pollinated by bees, which is confirmed by the present report. Other insects, as beetles (Vieira \& Lima 1997, Pansarin 2008) and flies (Pansarin 2008), only act as flower visitors. The observations of pollinator behavior on the flowers confirm that social and solitary bees of different sizes act as pollinators of Echinodorus grandiflorus. Some species should be highlighted because they were reported by other pollination studies on species of this genus. Exomalopsis fulvopilosa was also registered as a pollinator of $E$. grandiflorus in the State of Minas Gerais (Vieira \& Lima 1997) and of E. longipetalus in the interior of the State of São Paulo (Pansarin 2008). Another species registered as a pollinator of $E$. grandiflorus in populations of Minas Gerais is Protodiscelis echinodori (Vieira \& Lima 1997), while Xylocopa (NeoXylocopa) suspecta was also documented on flowers of E. longipetalus (Pansarin 2008).

The family Alismataceae presents a great diversity as for the reproductive system of its species. Genus Sagittaria comprises dioecious and monoecious species (Wooten 1971; Sarkissian et al. 2001). The flowers of Caldesia grandis Samuel. 
Table 2 - Bee species (pollinators) collected on flowers of Echinodorus grandiflorus and their body length (mm).

\begin{tabular}{lc}
\hline Bee species & Body length (mm) \\
\hline Apis mellifera L. & 14.5 \\
Augochlora sp. & 10.0 \\
Dialictus sp. & 6.0 \\
Exomalopsis fulvopilosa Spindola, 1853 & 10.5 \\
Pseudoaugochloropsis sp. & 8.0 \\
Protodiscelis echinodori Melo, 1996 & 7.0 \\
Thygater analis Lepeletier, 1841 & 12.0 \\
Trigona spinipes Fabricius, 1793 & 9.0 \\
Xylocopa (Neoxylocopa) suspecta Moure \& Camargo, 1988 & 28.0 \\
\hline
\end{tabular}

(Gituru et al. 2002), Baldellia ranunculoides (L.) Parl. var. ranunculoides and Baldellia alpestris (Cosson) Vasc. (Vuille 1988), and those of various species of Damasonium (Vuille 1987) are hermaphrodite and self-compatible. Although the species of Sagittaria occurring in this region are self-compatible, all are monoecious, and their inflorescences produce female flowers at base and male ones at apex, so that selfpollination is avoided by protogyny (Haynes \& Holm-Nielsen 1994; Pansarin \& Amaral 2005). Echinodorus longipetalus is gynodioecious: the hermaphrodite flowers are self-compatible, while the female ones necessarily need cross-pollination to yield fruits (Pansarin 2008). The occurrence of selfsterility, as seen in populations of $E$. grandiflorus from interior of the State of São Paulo, is rare in that family but had been previously reported for this species in the municipality of Viçosa, Minas Gerais (Vieira \& Lima 1997) and for a subspecies of Baldellia ranunculoides (Vuille 1988). According to Vieira \& Lima (1997), following the classification of Haynes \& Holm-Nielsen (1986, 1994), E. grandiflorus ssp. aureus is self-compatible, while $E$. grandiflorus ssp. grandiflorus is self-incompatible. Currently both subspecies have been heightened to the category of species by Lehtonen (2008). Echinodorus grandiflorus ssp. aureus is now a synonym for $E$. floribundus, while $E$. grandiflorus ssp. grandiflorus is a synonym for $E$. grandiflorus (Lehtonen 2008).

The most common mechanisms that tend to avoid self-fertility in Alismataceae are pre-pollination barriers. Within this family, the occurrence of protogyny was reported for species of Sagittaria (Pansarin \& Amaral 2005), while protandry occurs in Damasonium (Vuille 1987). Although the species of Sagittaria occurring in the neotropics are all monoecious (e.g., Rataj 1978; Haynes \& HolmNielsen 1986, 1994; Pansarin \& Amaral 2005), at least two North-American species (i.e., S. latifolia Willd. and S. lancifolia L.) have dioecious populations and, consequently, need cross-pollination (Wooten 1971; Sarkissian et al. 2001). Gynodioecy also favors the formation of fruits by cross-pollination in Echinodorus longipetalus (Pansarin 2008).

The populations of Echinodorus grandiflorus studied clearly show a post-pollination barrier that prevents the production of fruits as a result of selfpollinations. Hand self-pollination treatments indicate the occurrence of a late-acting self-incompatibility system, since the tubes present themselves well formed but the pistils abort circa 30 days after selfpollination. Some authors reveal that in systems of late-acting self-sterility, there are no differences in pollen tube growth between self- and cross-pollination treatments (e.g., Seavey \& Bawa, 1986). According to Gibbs (1990), mechanisms of late-acting selfincompatibility have proved relatively common in neotropical species, and were reported for various tree species (see Freitas \& Oliveira 2002). Nevertheless, for the populations of $E$. grandiflorus here analyzed, studies will be needed to confirm if ovules fertilize in flowers self-pollinated by hand and verify the kind of late-acting self-sterility mechanism involved.

Studies on tropical species of Alismataceae are extremely important, since many taxa are difficult to identify morphologically. Above all, in Brazil, the understanding of this family taxonomy presents gaps, mainly with regard to Echinodorus (Lehtonen 2008). Furthermore, features classically used to delimit genera, as the presence of unisexual (Sagittaria) or hermaphrodite (Echinodorus) flowers (Haynes \& Holm-Nielsen 1986, 1994; Pansarin \& 
Amaral 2005), can no longer be considered, since female flowers were found in populations of $E$. longipetalus (Pansarin 2008). As a consequence, research on the relations between the neotropical species of Echinodorus and Sagittaria, their pollinators and pollination mechanisms, their forms of reproduction, as well as the elaboration of phylogenetic hypotheses based on morphological and molecular features are needed to understand the taxonomy and the evolution of this subcosmopolitan family of monocots.

\section{Acknowledgements}

The authors thank A.R. Pinhal (Laboratory of Histology, FFCLRP-USP) for his help during the preparation of the slides, M.H. Pires (Laboratory of Plant Systematics, FFCLRP-USP) for help with laboratory procedures and S.R.M. Pedro (Laboratory of Systematics and Biogeography, FFCLRP-USP) for bee identification. L.M. Pansarin is a doctoral student at the Post-Graduation Program in Vegetal Biology of the State University of Campinas.

\section{References}

Campbell, D.R. 1987. Interpopulational variation in fruit production: the role of pollination-limitation in the Olympic Mountains. American Journal of Botany 74: 269-273.

Centurion, J.F.; Andrioli, L.; Marques Jr., J. \& Marchiori, D.G. 1995. Características de latossolos roxos desenvolvidos de rochas alcalinas e básicas de Jaboticabal, SP. Scientia Agricola (Piracicaba) 52: 226-232.

Cole, F.R. \& Firmage, D.H. 1984. The floral ecology of Platanthera blephariglottis. American Journal of Botany 71: 700-710.

Faegri, K. \& van der Pijl, L. 1980. The principles of pollination ecology. $3^{\text {a }}$ ed. Oxford, Pergamon Press.

Freitas, C.V. \& Oliveira, P.E. 2002. Biologia reprodutiva de Copaifera langsdorffii Desf. (Leguminosae, Caesalpinioideae). Revista Brasileira de Botânica 25: 311-321.

Gibbs, P.E. 1990. Self-incompatibility in flowering plants: a neotropical perspective. Revista Brasileira de Botânica 13: 125-136.

Gituru, W.R.; Wang, Q.; Wang, Y. \& Guo, Y. 2002. Pollination ecology, breeding system, and conservation of Caldesia grandis (Alismataceae), an endangered marsh plant in China. Botanical Bulletin of Academia Sinica 43: 231-240.

Haynes, R.R. \& Holm-Nielsen, L.B. 1986. Alismataceae. In: G. Harling \& L. Andersson. Flora of Ecuador 26: 1-24.
Haynes, R.R. \& Holm-Nielsen, L.B. 1994. The Alismataceae. Flora Neotropica Monograph 64: 1-112.

Johansen, D.A. 1940. Plant microtechnique. McGrawHill Book Co., New York.

Kearns, C. \& Inouye, W. 1993. Techniques for pollination biologists. University Press of Colorado, Niwot.

Köppen, W. 1948. Climatologia: um estúdio de los climas de la tierra. Fondo de Cultura Econômica, México.

Lehtonen, S. 2008. An integrative approach to species delimitation in Echinodorus (Alismataceae) and description of two new species. Kew Bulletin 63: 525-563.

Lehtonen, S. \& Myllys, L. 2008. Cladistic analysis of Echinodorus (Alismataceae): simultaneous analysis of molecular and morphological data. Cladistics 24 : 218-239.

Martin, F.W. 1959. Staining and observing pollen tubes in the style by means of fluorescence. Stain Technology 34: 125-128.

Pansarin, E.R. 2008. Reproductive biology of Echinodorus longipetalus (Alismataceae): sexual morphs, breeding system and pollinators. Aquatic Botany 89: 404-408.

Pansarin, E.R. 2009. Neotropikey: Interactive key to the flowering plants of the Neotropics - Family Alismataceae. Royal Botanical Gardens, Kew.

Pansarin, E.R. \& Amaral, M.C.E. 2005. Alismataceae. In: Wanderley, M.G.L.; Shepherd, G.J.; Giulietti A.M. \& Melhem, T.S. Flora fanerogâmica do estado de São Paulo. Rima, São Paulo. Pp. 1-10.

Pinto, M.M. 1989. Levantamento fitossociológico de uma mata residual: Campus de Jaboticabal da UNESP. Dissertação de Mestrado. Universidade Estadual Paulista, Jaboticabal.

Pissarra, T.C.T.; Politano, W. \& Ferraudo, A.S. 2004. Avaliação de características morfométricas na relação solo-superfície da Bacia Hidrográfica do Córrego Rico, Jaboticabal (SP). Revista Brasileira de Ciências do Solo 28: 297-305.

Radford, A.E.; Dickinson, W.C.; Massey, J. R. \& Bell, C.R. 1974. Vascular plant systematics. Harper \& Row, New York.

Rataj, K. 1978. Alismataceae of Brazil. Acta Amazonica 8: $1-53$.

Sarkissian, T.S.; Barrett, S.C. H. \& Harder, L.D. 2001. Gender variation in Sagittaria latifolia (Alismataceae): Is size all that matters? Ecology 82: 360-373.

Sass, J.E. 1951. Botanichal microtechnique. 2nd ed. The Iowa State College Press, Ames.

Seavey, S.R. \& Bawa, K.S. 1986. Late-acting selfincompatibility in Angiosperms. Botanical Review 52: 195-219.

Smith, G.R. \& Snow, G.E. 1976. Pollination ecology of Platanthera ciliaris and P. blephariglottis (Orchidaceae). Botanical Gazette 137: 133-140. 
Vieira, M.F. \& Lima, N.A.S. 1997. Pollination of Echinodorus grandiflorus (Alismataceae). Aquatic Botany 58: 89-98.

Vuille, F. 1987. The reproductive biology of the genus Damasonium (Alismataceae). Plant Systematics and Evolution 157: 63-71.
Vuille, F. 1988. The reproductive biology of the genus Baldellia (Alismataceae). Plant Systematics and Evolution 159: 173-183.

Wooten, J.W. 1971. The monoecious and dioecious conditions in Sagittaria latifolia L. (Alismataceae). Evolution 25: 549-553. 